\title{
Hematological abnormalities in HIV infected individuals in correlation to CD4 counts and ART status
}

\author{
Thulasi Raman R', D Manimaran², G Hemanathan ${ }^{3}$, Tameem Afroz ${ }^{4}$, Radha Sagar ${ }^{5}$ \\ ${ }^{1}$ Assistant Professor, Department of Pathology, Shri Sathya Sai Medical College and Research Institute, Ammapettai, \\ Chengalpet Taluk, Kancheepuram District, Tamil Nadu, ${ }^{2}$ Professor, Department of Pathology, Shri Sathya Sai \\ Medical College and Research Institute, Ammapettai, Chengalpet Taluk, Kancheepuram District, Tamil Nadu, \\ ${ }^{3}$ Resident, Department of Pathology, Shri Sathya Sai Medical College and Research Institute, Ammapettai, \\ Chengalpet Taluk, Kancheepuram District, Tamil Nadu, ${ }^{4}$ Senior Consultant, Department of Pathology, Aware Global \\ Hospitals, Hyderabad, Telangana, ${ }^{5} \mathrm{HOD}$ \& Senior Consultant, Department of Pathology, Aware Global Hospitals, \\ Hyderabad, Telangana
}

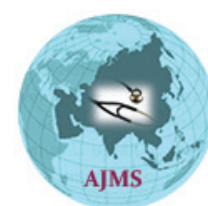

\section{A B S T R A C T}

Background: HIV is pandemic and remains as a public health concern for many decades. This infection though associated with many opportunistic infections and neoplasms, it is further complicated with marked hematological abnormalities. The aim of this study is to determine the magnitude \& severity of hematological abnormalities in HIV infected individuals and also to analyze these abnormalities in correlation with the CD4 counts. We also compared these hematological abnormalities in patients on ART and those not on ART. Materials and Methods: The study was conducted for a period of one year, on 120 HIV positive cases including both patients on ART \& not on ART. Controls with similar age and sex distribution was set up. The blood samples were collected and processed in an automated cell counter. The parameters were tabulated and analyzed with respect to CD4 count \& ART status. Results: Among the total of 120 HIV cases, $77 \%$ had anemia, $21 \%$ had leucopenia and $5 \%$ had thrombocytopenia. The magnitude and severity of anemia, leucopenia, thrombocytopenia and other parameters was found to be more in patients not on ART, when compared to patients on ART. Similarly, the magnitude and severity of most of hematological abnormalities were inversely proportional to the CD4 count in non-ART cases but not with cases on ART. Conclusion: The basic hematological parameters can be used as a prospective screening test to assess the severity and progression of HIV infection when CD4 count is not available. These parameters can also be used to assess the response to anti-retroviral treatment. Therefore, these basic hematological investigations readily available at all medical centers are of great use while treating HIV infected patients.

Access this article online

Website:

http://nepjol.info/index.php/AJMS

DOI: 10.3126/ajms.v7i4.14033

E-ISSN: 2091-0576

P-ISSN: $2467-9100$

Key words: Anemia, Leucopenia, Thrombocytopenia, HIV, CD4 Count, ART

\section{INTRODUCTION}

Human immunodeficiency virus (HIV) is a huge challenge to mankind and besieges world for many decades. Though various systemic manifestations either due to HIV infection itself, or associated opportunistic infections have been widely documented, only few attempts have been made to study the hematological abnormalities in this disease.
Hematological problems may be the first presentation of HIV infection. Patients may have no symptoms but be referred because of abnormal counts or lymphoid disorders. These hematologic manifestations are caused by the virus itself, other opportunistic infection, immune mechanisms, malignancies, drugs etc. The response of the body as mediated through cytokines and growth factors also results in impaired hematopoiesis, immune mediated 
cyopenias and other abnormalities. It affects all lineages of blood cells. ${ }^{1}$

HIV associated hematological abnormalities seem to be dependent on the level of viral replication, as these abnormalities are severe in late-stage acquired immunodeficiency syndrome (AIDS) patients with high viremia and decreased CD4 count. Hence these abnormalities worsens as the disease progresses to advanced stage ${ }^{1}$ and correlates with the severity of HIV-associated immunosuppression as measured by the CD4 cell counts. ${ }^{2}$ These hematological abnormalities are associated with increased morbidity and mortality in HIV infected patients affecting their quality of life. ${ }^{3}$

The aim of this study aim is to analyze the hematological abnormalities in HIV patients in correlation to CD4 count and anti-retroviral therapy (ART) status.

\section{MATERIALS AND METHODS}

\section{Study population setup}

Blood samples were collected from the HIV positive cases who were attending the anti-retroviral clinic, over a period of 30 days in May-June 2013. Cases were subjected to inclusion and exclusion criteria. HIV infected individuals between the age of 10-60, who were willing to participate was included in the study group after obtaining the consent. HIV cases who were not in the age range, pregnant and who were not willing to enroll themselves in the study were excluded. The total duration of the study was one year, and done on $120 \mathrm{HIV}$ positive cases $($ Male $=62$; Female $=58$ ) including both, patients on ART $(\mathrm{n}=76) \&$ those not on ART ( $\mathrm{n}=44$ ). A control of 40 apparently normal individuals (Male $=24$; Female $=16)$ within a range of 10-60 years of age was set up. Consent was obtained for each case and the required data was collected using a structured questionnaire.

\section{Blood counts}

Two $\mathrm{ml}$ of venous blood collected under aseptic precautions in two ethylene diamine tetra acetic acid (EDTA) vacutainers. One sample was analyzed using an automated hematology cell counter which was subjected to strict regular quality control programme. Hemoglobin $(\mathrm{Hb})$, white blood cells (WBC) count, platelet count was studied in cases and controls. Another sample was processed in a flow cytometer for CD4 counts.

\section{Methods of analysis}

A) Analysis of hematological parameters of HIV infected cases with Non infected controls.

- Each hematological parameter was comparatively studied between the cases and controls. The study attempted to analyze in detail, the severity of cytopenias in HIV infected patients. Hence anemia, leucopenia and thrombocytopenia were further graded as per severity. These parameters were graded as per national cancer institute (NCI) grading system. ${ }^{4}$ The parameters of blood indices (red blood indices and platelet indices) were divided as normal, above normal and below normal.

B) Analysis of hematological parameters in ART and NON-ART HIV positive cases with respect to CD4 count.

- The patients are separated into ART and Non ART group by their ART status during the time of sample collection. Hence few cases which were put on ART recently may slightly bias the data. To correlate with CD4 count, the patients of ART and Non-ART group were divided based on their CD4 counts (Graph 1).

- The CD4 count was taken in this study as a marker for disease severity. The CD4 counts were divided into intervals of 100 ie. $<100,101-200,201-300$, etc. The cases were distributed by their CD4 count in the respective interval. This was done to sort out the HIV cases by disease severity. A similar CD4 intervals were used by Akinbamiet al, ${ }^{5}$ in his study "Hematological abnormalities in treating naïve HIV patients" to bring out the relationship between varying degrees of CD4 count and cytopenias.

The statistical analysis is done using the SPSS statistical package.

\section{RESULTS}

Anemia in correlation with CD4 and ART status Among the total 120 HIV cases, 92 (77\%) cases had anemia and $28(23 \%)$ cases had normal Hb. 40 cases had mild anemia (Hb range 10-12g/dl), 37 cases had moderate anemia (Hbrange $08-10 \mathrm{~g} / \mathrm{dl}$ ) and 15 cases had

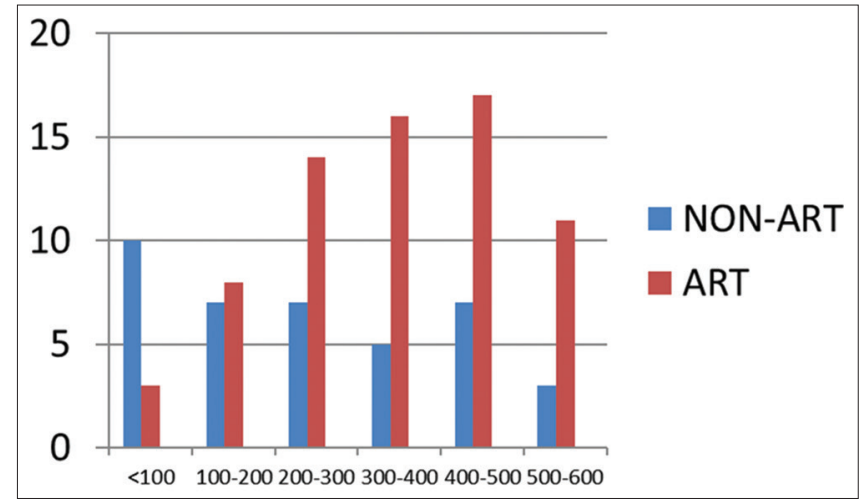

Graph 1: Distribution of cases according to cd4 count in art and non-art group 
severe anemia ( $\mathrm{Hb}$ ranging less than $8 \mathrm{~g} / \mathrm{dl}$ ) (Table 1$)$. The percentage of anemic cases were more on NON ART group (82\%) than ART group (74\%).

Majority $09(21 \%)$ of cases in NON ART groups, who had anemia fell in a CD4 count range of less than 100 and 06 cases each fell in a range of 101-200 and 201-300 (Table 3).

Leucopenia in correlation with CD4 and ART status Twenty-five HIV positive cases had leucopenia (ART= $19 \&$ NON ART $=06) .16$ cases had a WBC count ranging between $3-3.9 \times 10^{9} / \mathrm{L}(\mathrm{ART}=11 \& \mathrm{NON}$ ART $=05)$, 09 cases had a WBC count ranging between $2-2.9 \times 10^{9} / \mathrm{L}$ $($ ART $=08 \&$ NON ART $=01)$. No cases had a WBC count less than $1 \times 10^{9} / \mathrm{L}$ (Table 1$)$.

The percentage of leucopenic cases were more on ART group $(25 \%)$ than NON ART group (14\%). 04 out of 06, NON ART (67\%) cases had CD4 count less than 100 (Table 3).

Thrombocytopenia in correlation with CD4 and ART status

Only $06(05 \%)$ HIV positive cases had thrombocytopenia, of which $02(2.6 \%)$ were on ART and $04(09 \%)$ were not on

\begin{tabular}{|c|c|c|c|c|c|c|}
\hline \multirow[t]{2}{*}{ Cytopenia } & \multicolumn{2}{|c|}{$\begin{array}{l}\text { Patients not on } \\
\text { ART }(n=44)\end{array}$} & \multicolumn{2}{|c|}{$\begin{array}{l}\text { Patients on } \\
\text { ART }(n=76)\end{array}$} & \multicolumn{2}{|c|}{ Total } \\
\hline & No & $\%$ & No & $\%$ & No & $\%$ \\
\hline Anemia & 36 & 82 & 56 & 74 & 92 & 77 \\
\hline Leucopenia & 06 & 14 & 19 & 25 & 25 & 21 \\
\hline Thrombocytopenia & 04 & 09 & 02 & 03 & 06 & 05 \\
\hline
\end{tabular}

\begin{tabular}{|c|c|c|c|c|c|}
\hline \multirow[t]{2}{*}{ Parameter } & \multicolumn{2}{|c|}{$\begin{array}{l}\text { Controls } \\
(n=40)\end{array}$} & \multicolumn{2}{|c|}{$\begin{array}{l}\text { HIV infected } \\
\text { cases }(n=120)\end{array}$} & \multirow[t]{2}{*}{ p-value } \\
\hline & Mean & S.D & Mean & S.D & \\
\hline \multicolumn{6}{|l|}{$\mathrm{Hb}(\mathrm{g} / \mathrm{dl})$} \\
\hline Male & 13.9 & 1.06 & 10.7 & 2.32 & 0.001 \\
\hline Females & 12.6 & 0.80 & 10.0 & 1.66 & 0.002 \\
\hline WBC count $\times 10^{9} / \mathrm{L}$ & 8.565 & 1.915 & 5.773 & 2.270 & 0.253 \\
\hline Platelet count $\times 10^{9} / \mathrm{L}$ & 274 & 63 & 242 & 71 & 0.450 \\
\hline
\end{tabular}

ART [Table 1]. The percentage of Thrombocytopenic cases were more on NON ART group (09\%) than ART group $(03 \%)$. Out of 4 thrombocytopenic cases NOT ON ART, $03(75 \%)$ cases had CD4 count less than 200 [Table 3].

\section{DISCUSSION}

The present study was done in order to bring out the common hematological abnormalities encountered in HIV infected patients and to correlate these abnormalities with CD4 count, so that they can be used as a prognostic marker in resource limited settings.

The cases and controls in the present study, is concordant with other studies done by Karstaedt et $\mathrm{al}^{6}$ with respect to age and sex ratio.

\section{Anemia in HIV}

We found anemia $(77 \%)$ as the most common hematological abnormality and its incidence is associated with progression of HIV disease (Table 1). The incidence of anemia in HIV infected seropositive females (43\%) was more when compared to males $(33 \%)$. These findings were concordant with studies done by Ira Shah ${ }^{7}$ and Sullivan PS et al. ${ }^{8}$ Hemoglobin was significantly decreased in HIV cases when compared to controls (Table 2).

Among the 44 cases not on ART, anemia was found in $82 \%(n=36 / 44)$ [Table 1] and it's of moderate degree (8$9.9 \mathrm{~g} / \mathrm{dl}$ ) in many cases. Similarly among 76 cases on ART, anemia was found in $74 \%(n=56 / 76)$ and it's predominantly of milder degree $(10-11.9 \mathrm{~g} / \mathrm{dl})$. Thus the incidence and severity of anemia are slightly higher in patients not receiving ART therapy. This difference is probably due to improvement in hemoglobin after the initiation of HAART.

In the present study, 25\%(09/36) of anemic cases in the NON ART group fell within a CD4 count group of 0-100 cells $/ \mu \mathrm{L}$ (Table 3). Thus it's evident that the incidence of anemia increases as the CD4 count decreases. But a similar correlation was not obtained with cases on ART probably due to improvement with therapy.

The common cause of anemia in HIV infected patients is bone marrow failure and use of zidovudine. Other causes

Table 3: Comparison of hematological variables against HIV patients not on art and those on art

\begin{tabular}{|c|c|c|c|c|c|c|}
\hline \multirow{2}{*}{$\begin{array}{l}\text { Parameter } \\
\text { abnormality }\end{array}$} & \multicolumn{3}{|r|}{ Cases not on ART $(n=44)$} & \multicolumn{3}{|r|}{ Cases on ART (n=76) } \\
\hline & No & $\%$ & Maximum cases were in the CD4 range & No & $\%$ & Maximum cases were in the CD4 range \\
\hline Anemia & 36 & 82 & $0-100$ & 56 & 74 & $201-500$ \\
\hline Leucopenia & 06 & 14 & $0-100$ & 19 & 25 & $301-400$ \\
\hline Thrombocyto-penia & 04 & 09 & $0-100$ & 02 & 03 & $0-100 \& 201-300$ \\
\hline
\end{tabular}


like autoimmune antibodies to hemopoietic precursors, opportunistic infections like Cytomegalovirus (CMV), B19 parvovirus, or Mycobacterium avium-intracellulare suppressing erythropoiesis, hemolytic anemia, anemia related to gastrointestinal bleeding, decreased erythropoietin levels, Nutritional anemia due to B12 and iron deficiency resulting from malabsorption or malnutrition have also been stated.?

\section{Leucopenia in HIV}

As encountered by Akinsegun Akinbami et $a l,{ }^{5}$ in the present study, we found 25 out of 120 cases (21\%) having leucopenia (Table 1). Among the 44 cases which were not on ART, mild to moderate leucopenia was found in 19\% $(\mathrm{N}=6 / 44)$ of cases. Similarly among 76 cases on ART, leucopenia was found in 25\% (19/76) of cases and its of mild degree except one case. Thus the incidence and severity of leucopenia is slightly higher in patients receiving ART therapy. This is probably due to the toxicity of the anti-retroviral therapies.

Out of 6 cases having leucopenia in the non- ART group, 4 cases ie. $67 \%$ had a CD 4 count less than 100 cells/ $\mu$ l (Table 3). Here too like anemia there is no correlation found with CD4 count in cases on ART therapy, but the incidence of leucopenia is more among patients with low CD4 counts in NON ART group.

The causes for leucopenia is probably due to toxicity of therapies for HIV or associated conditions. An autoimmune mechanism involving antigranulocyte antibodies and impaired granulopoiesis and any infiltrative process involving the bone marrow (infection, malignancy) has also been postulated. ${ }^{10}$

\section{Thrombocytopenia in HIV}

In the present study, we encountered only $5 \%$ of mild thrombocytopenic cases (Table 1). Similarly Byomakesh Dikshit et a ${ }^{11}$ and Gul Cunha de Santis et a ${ }^{12}$ also showed only a limited increase in the number of thrombocytopenic cases in their cohort group.

The incidence of thrombocytopenia is slightly higher in patients not receiving ART therapy in contrast to those on ART. This difference is probably due to improvement in disease after the initiation of HAART. We observed 50\% (2/4) of thrombocytopenic cases in the NON ART group fell within a CD4 interval of $0-100$ cells $/ \mu \mathrm{l}$ (Table 3). Thus it's evident that the incidence of thrombocytopenia is high with low CD4 counts. But a similar correlation was not obtained with cases on ART, probably due to recovery after therapy.

Thrombocytopenia in HIV infection, is also due to increased platelet destruction by deposition of circulating immune complexes on platelets. Presence of specific antiplatelet antibodies and direct infection of megakaryocytes by HIV are also being hypothesized. ${ }^{5}$

We encountered bicytopenia in 20\% (24/120) of cases and only one pancytopenia. Byomakesh Dikshit et al, ${ }^{11}$ encountered Pancytopenia in 6\% (12/200) of cases in their cohort study. Sitalakshmi et al, ${ }^{13}$ and Spivak J et al, ${ }^{14}$ also reported fewer cases of pancytopenia in their HIV cohort study group.

Pancytopenia occurs frequently in HIV-1-infected patients, especially during advanced stages of the disease. ${ }^{15}$ Multiple pathogenic mechanisms have been suggested, including impaired hematopoiesis and immune-mediated. ${ }^{16}$ Cytopenia can result from HIV infection, opportunistic infections, or as a consequence of drug treatment. HIV can directly infect the bone marrow cells and the release of viral proteins is believed to have cytotoxic effects on marrow stem cells. ${ }^{1}$

Though this study brings out the common hematological abnormalities encountered in HIV patients, we couldn't find the exact cause of such abnormalities in our patients. Further studies like investigation of bone marrow stem cells in HIV patients will help us in understanding the cause of these hematologic abnormalities.

\section{CONCLUSION}

The basic hematological parameters like hemoglobin, total leukocyte count along with platelet count can be used as a prospective screening test to assess the severity and progression of HIV infection when CD4 count is not available, especially in developing countries like India where financial resources are slightly limited. These parameters can be used to assess the response to antiretroviral treatment. Hence Clinicians can utilize these basic investigations readily available at all medical centers while treating HIV infected patients.

Key message: Routine hematological parameters are of great use in predicting the severity \& progression of HIV infection and also to assess the response to anti-retroviral treatment.

\section{REFERENCES}

1. Servais J, Nkoghe D, Schmit JC, Arendt V, Robert I, Staub T, et al. HIV-Associated Hematologic Disorders Are Correlated With Plasma Viral Load and Improve Under Highly Active Antiretroviral Therapy. J Acquir Immune Defic Syndr 2001; 28(3):221-225.

2. Elaine M. Sloand and Jerome E. Groopman. Acquired 
Immunodeficiency Syndrome. In: John P. Greer, John Foerster, George M. Rodgers, Frixos Paraskevas, Bertil Glader, Daniel A. Arber, Robert T. Means Jr. Wintrobes clinical hematology, 12 edition. Philadelphia, Lippincott Williams \& Wilkins Publisher. 2009; 1623-1636

3. Abebe $\mathrm{M}$ and Alemseged F. Hematologic abnormalities among children on HAART, in jimma university specialized hospital, south western ethiopia. Ethiop J Health Sci 2009;19(2):83-89.

4. National cancer institute $(\mathrm{NCl})$ Toxicity criteria. http://www. download.bham.ac.uk/bctu/AML16/Trial/DocsForExisting Centres/National Cancer Institution $\mathrm{NCl}$ Toxicity Criteria formatted.pdf

5. Akinbami A, Oshinaike O, Adeyemo T, Adediran A, Dosunmu O, Dada M, et al. Hematologic Abnormalities in Treatment-naïve HIV patients. Infectious Diseases: Research and Treatment 2010;3: 45-49.

6. Karstaedt AS, Pantanovitz L, Omar T, Sonnendecker HE and Patel M. Utility of bone marrow examination in HIV infected adults in South Africa. Q J Med 2001; 94: 101-105.

7. Shah I and Katira B. Hematological Manifestation in HAART Naive HIV-1 Infected Children in India in a Resource Limited setting. Pediatric Oncall [Serial online] 2011 [cited 2011 May 1]; 8. Art \# 35. Available from http://www.pediatriconcall.com/ fordoctor/Medical_original_articles/hiv1.asp.

8. Sullivan PS, Hanson DL, Chu SY, Jones JL and Ward JW. Epidemiology of anemia in human immunodeficiency virus (HIV)-infected persons: results from the multistate adult and adolescent spectrum of HIV disease surveillance project. Blood 1998; 91:301.

9. Murphy MF, Metcalfe P, Waters AH, Carne CA, Weller IV, Linch DC, et al. Incidence and mechanism of neutropenia and thrombocytopenia in patients with human immunodeficiency virus infection. Br J Haematol 1987; 66:337-340.

10. Donald W. Northfelt, MD, Mayo Clinic, Scottsdale, Arizona. Hematologic Manifestations of HIV. http://hivinsite.ucsf.edu/ InSite?page=kb-04-01-09. (Published February 1998).

11. Dikshit B, Wanchu A, Sachdeva RK, Sharma A and Das R. Profile of hematological abnormalities of Indian HIV infected individSuals. BMC Blood Disorders 2009; 9:5.

12. De Santis GC, Brunetta DM, Vilar FC, Brandao RA, de Albernaz Muniz RZ, Nogueira de Lima GM, et al. Hematological abnormalities in HIV-infected patients. International Journal of Infectious Diseases 2011; 15 (12): e808-e811.

13. Sitalakshmi S, Srikrishna A and Damodar P. Hematological changes in HIV infection. Indian J Pathol Microbiol 2003; 46(2):180-183.

14. Spivak JL, Bender BS and Quinn TC. Hematologic abnormalities in the acquired immune deficiency syndrome. Am J Med 1984; 77(2):224.

15. Opie J. Hematological complications of HIV infection. S Afr Med J 2012; 102(6): 465-468.

16. Moller T and Hasselbalch HC. Hematological changes associated with human immunodeficiency virus (HIV-1) infection. Ugeskr Laeger 1993;155(19):1442-1446.

Authors Contribution:

TRR - Concept and design of the study, collected data, statistically analyzed, reviewed the literature, manuscript preparation and critical revision of the manuscript; MD - Concept and design of the study AND critical revision of the manuscript; HG - statistically analyzed AND reviewed the literature; TA - Concept and design of the study; RS - Concept and design of the study.

Source of Support: Nil. Conflict of Interest: None. 